The 3rd International Conference on Biological Science 2013

(The 3rd ICBS-2013)

\title{
EFFECT of Aloe vera EXTRACT TO THE INSULIN-LIKE GROWTH FACTOR-1 (IGF-1) LEVELS FROM VISCERAL FAT TISSUE IN Rattus norvegicus WISTAR DIABETES MELLITUS
}

\author{
Lulut Dwi Nurmamulyosari ${ }^{1}$, Muhammad Rifqi Hariri², Abdul Gofur ${ }^{3}$, Dwi Listyorini ${ }^{3}$, \\ Hendra Susanto ${ }^{3}$, and Adeodatus Yudha Handaya ${ }^{4}$ \\ ${ }^{1}$ Postgraduate Student of Biology Department, Postgraduate Programme Universitas Brawijaya \\ 2 Postgraduate Student of Biology Department, Faculty of Mathematics and Natural Sciences \\ Institut Pertanian Bogor \\ ${ }^{3}$ Biology Department, Faculty of Mathematics and Natural Sciences Universitas Negeri Malang \\ ${ }^{4}$ Faculty of Medicine Universitas Brawijaya \\ Correspondence author: Iulut.dwi.n@gmail.com
}

\begin{abstract}
Diabetes mellitus is a metabolic disorder indicated by hyperglycaemia due to lack of insulin production, insulin activity, or both. It causes oxidative stress that may damage the receptor of Growth Hormone Releasing Hormone (GHRH) in the pituitary. As the result, Growth Hormone (GH) and Insulin-like Growth Factor-1 (IGF1) production are decreased and glucose uptakes to the cell is inhibited. Aloe vera has a high antioxidant activity. It is possible to counter oxidative stress in unregulated the production of IGF-1. This study aimed to determine the effect of $A$. vera extracts to the level of IGF-1 from visceral fat tissue Rattus norvegicus wistar diabetes mellitus. This study used $24 R$. norvegicus wistar male. $R$. norvegicus STZ-induced diabetes mellitus $R$. norvegicus were grouped into positive control (C+), $30 \mathrm{mg} /$ day, $60 \mathrm{mg} /$ day, $120 \mathrm{mg} /$ day. Fasting blood glucose test was performed to determine the successful induction of diabetes mellitus (DM) three days after induced. Non-DM rats (NDM) were grouped into negative control (C-), $30 \mathrm{mg} / \mathrm{day}, 60 \mathrm{mg} /$ day, and $120 \mathrm{mg} /$ day. Each group was consisting of three replications. Each animal, except the controls, were treated $3 \mathrm{ml}$ suspension of $A$. vera extract for 14 days by gavage. IGF-1 levels were measured using indirect ELISA. The result showed that the extract of $A$. vera significantly influenced the IGF-1 levels in DM group. The dose of 60 and $120 \mathrm{mg} /$ day significantly raised the level of IGF-1 compared to C+. In NDM group the dose of $60 \mathrm{mg} /$ day significantly raised the level of IGF-1 compared to C-.
\end{abstract}

Key words: Aloe vera, Rattus norvegicus, IGF-1, visceral fat, diabetes mellitus

\section{INTRODUCTION}

Diabetes mellitus is a chronic disease and known as Non-Communicable Diseases (NCD) which commonly occurs in various regions of the world. Death due to NCDs globally increased by $15 \%$ from 2010 to 2020 . The largest increased about $20 \%$, was observed in African region, East Mediterania, and Southeast Asia (WHO, 2010). WHO reported that the incidence of diabetes mellitus by 364 million people around the world. Based on the final diagnosis, a total sample of 24,417 from Indonesia's population aged over 15 years had shown that as many as $10.2 \%$ were having diabetes mellitus and $5,3 \%$ at a young age (age 15-24 years). There are two types of diabetes mellitus, diabetes mellitus type 1 is characterized by insulin deficiency and diabetes mellitus type 2 is due ineffective function of insulin. A person suffering from diabetes mellitus characterized by the level of fasting plasma glucose (FPG) of $125 \mathrm{mg} / \mathrm{dl}$ which equal to $200 \mathrm{mg} / \mathrm{dl}$ two hours after eating. Long-term chronic hyperglycaemia can lead to various organs complications, such as blindness, kidney failure, ulcers, sexual dysfunction, cardiovascular disease, and liver disorders (WHO, 2011 ${ }^{\text {; }}$ WHO, $\left.2011^{\mathrm{b}}\right)$.

ISSN 2413-0877 (C) 2015 The Authors.

Published by KnowledgeE Publishing Services This is an open access article under the CC BY-NC-ND license (http://creativecommons.org/licenses/by-nc-nd/4.0)

Selection and Peer-review under responsibility of the 3rd ICBS-2013

Doi http://dx.doi.org/10.18502/kls.v2i1.138 
Hyperglycaemia causes oxidative stress which produces more free radicals than antioxidants in the body. Oxidative stress may cause damage to the Growth Hormone Releasing Hormone (GHRH) receptor in pituitary which affects the secretion of Growth Hormone $(\mathrm{GH})$ and reduced the production of Insulin-like Growth Factor-1 (IGF-1). When production of IGF-1 is low, so does the formation of receptor glucose and it will aggravate the condition of hyperglycaemia because the glucose that enters the cell is low and the energy needed will be slightly gained. In order to fulfill the energy requirement, body will acquire it from fat. Fat molecules are broken down into fatty acids and caused ketoacidosis due to the rising of acid levels in blood (Forbes et al., 2008; Bedard et al., 2008; Riddell \& Perkins, 2006).

In order to return the production of IGF-1 to normal, the GHRH receptor damage must be minimized by reducing the oxidative stress. The stress condition can be improved if the production of free radicals and antioxidants are well-balanced. Antioxidant are substances that can scavange the oxidized substrate and inhibit the oxidation of certain substrates (Hlliwell \& Gutteridge In: Droge, 2002). There are many different kinds of plants contains high antioxidant, such as Aloe vera which is commonly used as a remedy for various diseases and can be used as astringent, hemostatic, antiseptic, antibacterial, anti-inflammatory, anticancer, and antidiabetic (Rajasekaran et al., 2006; Afaf et al,. 2008; Joseph \& Raj, 2010).

Aloe vera extract can lower glucose levels in diabetic rats and rabbit blood. The decreasing glucose level indicates that the extract $A$. vera stimulates insulin secretion and the regeneration of pancreatic $\beta$-cells (Saif-Ur-Rehman et al., 2011; Sujono \& Wahyu, 2005; Solomon et al. within Yeggnisetty et al., 2012). Aloe vera contains about 200 different substances benefits for human health including vitamins, enzymes, minerals, amino acids, and antioxidant (Joseph \& Raj, 2010). Natural antioxidants that are found in leaf gel of $A$. vera are vitamin $\mathrm{A}$, vitamin $\mathrm{C}$, vitamin $\mathrm{E}$ (Miladi \& Damak, 2008). Thus, $A$. Vera might be a potential source for antioxidant that reduce the ROS level in the body and suppress the occurence of oxidative stress.

\section{MATERIALS AND METHODS}

\section{Animal Preparations}

A total of 24 male of $R$. norvegicus Wistar (150-200 g) were divided into 12 nondiabetic mellitus (NDM) and 12 streptozotocin (STZ)-induced diabetic mellitus (DM) by $60 \mathrm{mg} / \mathrm{Kg}$ $B W$ via intraperitoneal injection. Three days later, the fasting blood glucose test was performed to determine the successful induction of diabetes mellitus. NDM group were divided into negative control (C-), NDM1 (30 mg/day), NDM2 (60 mg/day), NDM3 (120 mg/day). DM group was divided into positve control (C+), DM1 (30 mg/day), DM2 (60 mg/day), DM3 (120 $\mathrm{mg} /$ day). Each group consisted of three replicate. In each group except the control were given $3 \mathrm{ml}$ suspension of extract $A$. vera with doses of 30,60 , and $120 \mathrm{mg} /$ day by gavage for 14 days.

\section{Aloe vera Extract Preparations}

Leaves of healthy $A$. vera obtained in the area of Malang/Batu were cleaned using calcium hipoclorite and distilled water. After no mucous left, the leaves were cut on the base about $1 \mathrm{~cm}$ and the flesh was taken. The flesh was rinsed under the running tap water then 
cut into small pieces and blended. After that, the gel soaked using ethanol $96 \%$ (1:4 v:v) and stirred for $10 \mathrm{~h}$ at $30^{\circ} \mathrm{C}$, allowed for precipitation for $10 \mathrm{~h}$ at $10^{\circ} \mathrm{C}$. The sediment was separated from the solution by filtration and dried with vacuum dryer at $50^{\circ} \mathrm{C}$ (Padmadisastra et al., 2003; Kusumawati \& Pratiwi, 2009).

\section{Determination of IGF-1 Level in Visceral Fat Tissue}

Two weeks after the treatment, all of the $R$. norvegicus were decapitated and the visceral fat tissue was taken. A total of $50 \mathrm{mg}$ tissue were grinded and added with $500 \mu \mathrm{l}$ Radioimmuno Precipitation Assay (RIPA) buffer lysis. The suspensions were then vortexed and incubted at $4^{\circ} \mathrm{C}$ for 30 mins. After 30 mins incubation, the fat tissue suspensions were centrifuged at $12,000 \mathrm{rpm}$ for $20 \mathrm{mins}$. The supernatant was taken and moved to a new microtube to measure the IGF-1 level using ELISA reader at $492 \mathrm{~nm}$ (Titer Assay Enzyme Design EIA Kit, Catalog No. 900-101).

\section{Statistical Analysis}

The data was in the form of absorbance values and determination of the IGF-1 level measurement used standard curve $y=0.0003 x+0.0008$. The statistic analysis was performed using One way ANOVA $(p<0.05)$ and followed by LSD.

\section{RESULT AND DISCUSSION}

The result of IGF-1 measurements on visceral fat tissue of $R$. norvegicus showed that the extract of $A$. vera increased the levels of IGF-1 (Figure 1). ANOVA test was able to show that the treatment using $A$. vera extract was significantly affect IGF- 1 levels $(p<0.05)$. LSD test showed that the levels of IGF-1 on visceral fat tissue $R$. norvegicus diabetes mellitus which were treated with $60 \mathrm{mg} /$ day and $120 \mathrm{mg} /$ day were significantly different compared to the positive control $\left(\mathrm{C}_{+}\right)$and $30 \mathrm{mg} /$ day on $R$. norvegicus DM group whereas in NDM group there was showed that $60 \mathrm{mg} /$ day $A$. vera extract treatment was significantly different compared to negative control (C-), but not significantly different compared to $30 \mathrm{mg} /$ day and 120 $\mathrm{mg} /$ day dosage.

Streptozotocin is a compound that can cause a quick damage to pancreatic beta cells so that insulin production is reduced ( $\mathrm{Pi}$ et al., 2007) and based on the data STZ administration was succesfully induced diabetes mellitus. Decreased insulin production can lead to hyperglycemia. Hyperglycemia causes oxidative stress conditions and may cause damage

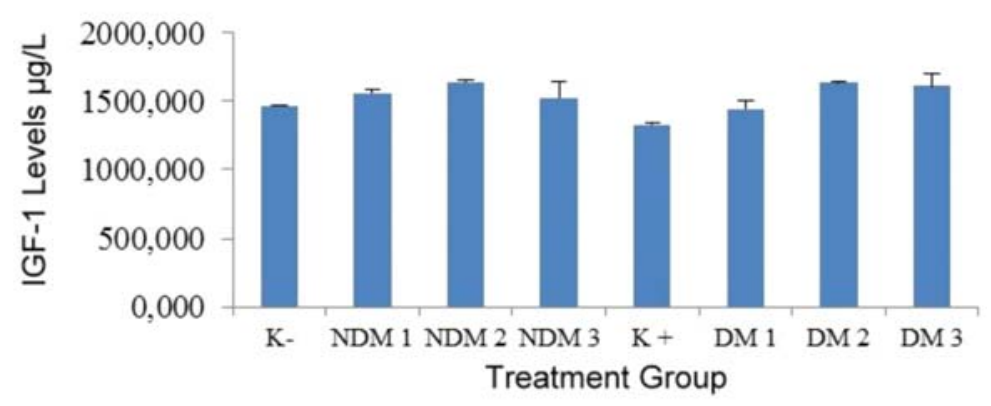

Figure 1. IGF-1 Levels on DM and NDM Rattus norvegicus Visceral Fats Tissue. Data present the mean of three replicates and the standard error. 
in the pituitary GHRH receptors that results in the decreased secretion of $\mathrm{GH}$. When $\mathrm{GH}$ secretion decreases, so does the IGF-1 production in the liver (Forbes et al., 2008; Bedard et al., 2008). The extract given to $R$. norvegicus DM was able to increase the levels of IGF1. Perhaps, it was possible because $A$. vera has a high antioxidant activity which reduces the concentration of free radicals by $50 \%$ and can inhibit the release of ROS from phorbol 12-myristate 13-acetate (PMA). The other content is enzyme SOD which is thought that the increased production of SOD leads to cell protecting mechanism against free radical exposure (Hart et al., 1990; Hamman, 2008; Khaing, 2011; Erejuwa et al., 2011).

The presence of antioxidants can reduce oxidative stress so that the pituitary GHRH receptor synthesis can be returned to normal and the production of GH and IGF-1 will be improved. The other mechanism that can improve the production of IGF-1 comes from polysaccharides Acemannan which acts as an antioxidant and expected to repair damaged pancreatic $\beta$ cells (Chun-hui In : Cock, 2011; Hamman, 2008). In this study the extraction process was using ethanol $96 \%$ as precipitant which will generate a lot of acemannan polysaccharides according to Kusmawati \& Pratiwi (2009).

The mechanism of $\beta$-cell repairing is analogous to glucomannan polysaccharides that can increase the mRNA gene of proinsulin levels in rats with diabetes mellitus. An increase in mRNA level is characterized by an increase in the number of $\beta$-cells and so does the the production of insulin (Fatchiyah, 2011). Increased insulin production can improve the conditions of hyperglycemia and pressing the oxidative stress. The oxidative stress can be reduced if the production of IGF-1 can be returned to normal. The biological activity can occur not only one compound that works, but a whole compounds contained in $A$. vera extract that work synergistically (Dagne et al., In: Hamman, 2008)

Based on the result, $A$. vera can be used as a candidate to treat diabetes mellitus due to the increased levels of IGF-1 and the hyperglycemia seems to be inhibited as well so that the danger of cell damage caused by oxidative stress can be avoided. In addition, the glucose is able to enter the cells and can be used as energy and the use of fat catabolism can be minimized so that ketoacidosis can be avoided. The dose extract of $30 \mathrm{mg} /$ day didn't significantly affect the levels of IGF-1 on $R$. norvegicus normal compared to C- treatment, but the dose of $60 \mathrm{mg} /$ day was significant. In both DM and NDM groups, the levels of IGF-1 on $R$. norvegicus given with $120 \mathrm{mg} /$ day were lower than treated rats with $60 \mathrm{mg} / \mathrm{day}$. It is possible that the highest dose (20 mg/day) has been overeffective so that it can disrupt the physiology of the body. Mali et al. (2011) mentioned that $A$. vera overdose can result in side effects such as lack of electrolytes, fluid imbalance, and intestinal cramps. Therefore the provision of $A$. vera as much as $120 \mathrm{mg} /$ day are not recommended.

\section{CONCLUSION}

The extract of $A$. vera significantly increased the IGF-1 levels on $R$. norvegicus visceral fat tissue DM via oral administration with dose $60 \mathrm{mg} /$ day and $120 \mathrm{mg} /$ day compared to $\mathrm{C}_{+}$ whereas on normal $R$. norvegicus visceral fat tissue, the extract of $A$. vera seemed to increase the IGF-1 levels in dose $60 \mathrm{mg} /$ day compared to C-. Thus, dose of $60 \mathrm{mg} /$ day $A$. vera extract is suggested to be an alternative dose treatment for DM. 


\section{REFERENCES}

Afaf, I. Abuelgasim, M.K.M. Osman, and B. Elmahdi. 2008. Effect of Aloe vera (Elsabar) Ethanolic Extract on Blood Glucose Level in Wistar Albino Rats. Journal of Applied Science Research. 4(12): 1841-1845.

Bedard, K., J. Strecko, K. Theriault, J. Bedard, C. Veyrat-Durebex, and P. Gaudreau. 2008. Effect of a High-Glocose Environment on the Pituiry Growth Hoemone-Realising Hormone Receptor: Type 1 Diabetes Compared with in vitro Glucoxity. Am J Physiol Endocrinol Metabolism. 294: E740 - E751.

Cock, I.E. 2011. Problems of Reproducibility and Efficacy of Bioassay Using Crude Extracts, with reference to Aloe vera. Pharmacognosy Communication. 1(1): 52-62.

Droge, W. 2002. Free Radicals in Physiological Control of Cell Function. Physiol Rev. 82: 47-97.

Erejuwa, O.O., S.A. Sulaiman, M.S.A. Wahab, S.K.N. Salam, M.S.M. Salleh, and S. Gurtu. 2011. Effect of Glibenclamide alone versus Glibenclamide and Honey on Oxidative Stress in Pancreas of Streptozotocin Induced Diabetic Rats. International Journal of Applied Research in Natural Products. 4(2): 1-10.

Fatchiyah. 2011. Glucomannan, Terapi Herbal Pengendalian Gula Darah pada Diabetes. http://fatchiyah.lecture.ub.ac.id/2011/06/glucomannan-terapi-herbal-pengendaliangula-darah-pada-diabetes/, accessed 2 June 2012.

Forbes, J.M, M.T. Coughlan, and M.E. Cooper. 2008. Oxidative Stress as a Major Culprit in Kidney Disease in Dibetes. Diabetes. 52: 1446-1454.

Hamman, J.H. 2008. Composition and Applications of Aloe vera Leaf Gel. Molecules. 13: 1599-1616.

Hart, L.A., P.H. Nibbering, M.T. van den Barselaar, A.J. van den Berq, and R.P. Labadie. 1990. Effect of Low Molecular Constituents from Aloe vera Gel on Oxidative Metabolim and Cytotoxic and Bactericidal Activities of Human Neutrophils. International Journal Immunopharmacology. Abstract. 12(4): 427-34.

Joseph, B., and S.J. Raj. 2010. Pharmacognostic and Phytochemical Properties of Aloe Vera Linn An Overview. International Journal of Pharmaceutical Sciences Review and Research. 4(2): 106-110.

Khaing, T.A. 2011. Evaluation of the Antifungal and Antioxidant Activities of Leaf Extract of Aloe vera (Aloe barbadensis Miller). World Academy of Science, Engineering and Technology. 75: 610-612.

Kusmawati, A., and I.B. Pratiwi. 2009. Pengambilan Polisakarida Acemannan dari Aloe vera Menggunakan Etanol sebagai Pengendap. Semarang: Jurusan Teknik Kimia, Fakultas Teknik, Universitas Diponegoro.

Mali, R.A., S.R. Pattan, R.Y. Patil, A.M. Vayakole, P.S. Pedagonkar, U.D. Gharte, R.S. Jadhav, and D.G. Baheti. 2011. Need and Scope of Development of Aloe vera as Remedy Medicine For Skin Diseases. Pharmacologyonline. 1: 602-616.

Miladi, S., and M. Damak. 2008. In Vitro Antioxidant Activities of Aloe vera Leaf Skin Extracts. Journal del la Societe Chimique de Tunisie. 10: 101-109.

Padmadisastra, Y., Sidik, and S. Ajizah. 2003. Formulasi Cair Gel Lidah Buaya (Aloe vera Linn.) Sebagai Minuman Kesehatan. Simposium Nasional Kimia Bahan Alam III. 1-13. 
Pi, J., Y. Bai, Q. Zhang, V. Wong, L.M. Floering, K. Daniel, J.M. Reece, J.T. Deeney, M.E. Anderson, B.E. Corkey, and S. Collins. 2007. Reactive Oxygen Species as a Signal Glucose-Stimulated Insulin Secretion. Diabetes. 56: 1783-1791.

Rajasekaran, S., K. Ravi, K. Sivagnanam, and S. Subraimanian. 2006. Benefical Effects of Aloe vera Leaf Gel Extract in Lipid Profile Status in Rats With Streptozotocin Diabetes. Clinical and Experimental Pharmacology an Physiology. 33: 232-237.

Riddel, M.C., and B.A. Perkins. 2006. Type 1 Diabetes and Vigorous Exercise: Applications of Exercise Physiologhy to Patient Management. Canadian Journal of Diabetes. 30(1). 63-71.

Saif-Ur-Rehman, S.A. Jafri, S. Hassan, I. Ahmed, and M. Naim. 2011. Study on Antidiabetic of Aloe vera Extract on Alloxan Induced Diabetic Rats. Libyan Agriculture Research Center Journal International. 2(1): 29-32.

Sujono, T.A., and A.S. Wahyuni. 2005. Pengaruh Decocta Daun Lidah Buaya (Aloe vera L) terhadap Kadar Glukosa Darah Kelinci yang Dibebani Glukosa. Journal Penelitian Sains \& Teknologi. 6(1): 26-34.

World Health Organization (WHO). 2010. Global Status Report on Noncommunicable Diseases 2010. Geneva: WHO

World Health Organization (WHO). 2011 ${ }^{\text {a }}$. Diabetes. http://www.who.int/mediacentre/ factsheets/fs312/en/index.html, accessed 31 May 2012.

World Health Organization (WHO). 2011 . Noncommunicable Disease in the South-East Asia Region. New Delhi: WHO.

Yeggnisetty, R.M., Ramachandraiahgari, S.R. Somesula, P.J. Adi, I.S. Mannur, and B.M. Enamala. 2012. Protective role of Ethanolic Extract of Aloe vera Antioxidant Properties on Liver and Kidney of Streptozotocin-Induced Diabetic Rats. Digest Journal of Nanomaterials and Biostructures. 7(1): 175-184. 